\title{
Unpacking the right-populist threat to climate action: Poland's pro- governmental media on energy transition and climate change
}

\author{
Piotr Żuk PhD, a) University of Wrocław, Department of Sociology, b) The Centre for Civil \\ Rights and Democracy Research, e-mail: pzuk@uni.wroc.pl , tel. +48 669230 225;
}

Kacper Szulecki PhD, a) University of Oslo, Department of Political Science, b) ESPRi -

Environmental Studies and Policy Research Institute, Wroclaw e-mail:

kacper.szulecki@stv.uio.no

Address for the corresponding authors:

\section{Instytut Socjologii, ul. Koszarowa 3,}

\section{1-149 Wroclaw, Poland}

\begin{abstract}
Is populist politics a threat to ambitious climate action and decarbonisation of energy systems? With the coinciding challenges of an alleged global 'populist wave,' and the growing visibility of a planetary climate crisis, this issue has gained relevance. While theoretical literature on the links between populism and climate action is growing, there is still little empirical evidence regarding the ways in which the thin ideology of populism can interact with climate policy in practice (particularly in the context of Eastern Europe). We look into this black box, by analyzing the Polish right-wing populist media discourses on energy and climate. Poland is widely perceived as a laggard in European climate policy and energy transition, seeking to safeguard domestic coal as a major energy source and opposing ambitious decarbonisation goals. At the same time, since 2015 it has seen a right-wing populist government in power, making it a very interesting case for an analysis of the interaction of populist politics and climate action. Using four key elements of populist political rhetoric as a framework (a populist episteme, Manichean good and evil connotations and internal enemies) we organize the arguments distilled from a wide reading of pro-governmental right-wing Polish media, to illustrate the content of populist climate and energy discourse, seeing some of the tropes found in our case as generalizable to other national contexts.
\end{abstract}




\section{Introduction: Climate policy in the shadow of right-wing populism}

Although the rise of right-wing populism (RWP) in various parts of the world (e.g. Brazil, Central-Eastern European countries, United States) is primarily associated with the upsurge of nationalism, aversion to cultural diversity, and a negative attitude towards migrants, its cultural impact is wider. It also engages the issues of science and environmentalism, including the question of anthropogenic climate change.

At the 2018 United Nations Climate Change Conference (COP24), held in Katowice, Andrzej Duda, the right-wing president of Poland, stated: 'There is no plan to abandon coal in Poland. Coal is our strategic raw material. We have supplies for 200 years and it is difficult for us to give up coal, thanks to which we have energy sovereignty' [1].

This coincided with many statements from Donald Trump, the president of the United States (US), who claimed that he did not believe that climate change would cause havoc in the American economy [2]. He went so far as suggesting its positive effects: 'the US would benefit from "a little of that good old fashioned Global Warming right now" amid forecasts of snow and cold conditions' [3]. In turn, the administration of Jair Bolsonaro, the ultraconservative populist president of Brazil, does not accept the evidence of climate change at all-according to its minister of foreign affairs, it is part of a plot by 'cultural Marxists' to stifle western economies and promote the growth of China [4]. Along similar lines, Witold Waszczykowski, Poland's minister of foreign affairs in the right-wing populist Law and Justice (PiS) government, suggested all environmentalism was part of a 'Marxist culture,' referring to his predecessors in government who:

'carried out a leftist programme [in the public media]. It was as if the world was according to a Marxist model which has to automatically develop in one direction only - a new mixture of cultures and races, a world made up of cyclists and vegetarians who only use renewable energy and fight all forms of religion' (as quoted in [5]).

This scattered evidence seems to confirm the broad assumption social scientists make about the negative impact of right-wing populist politicians on domestic and international climate policy ambitions. However, while the general theoretical premises for this relationship have been laid out [6,7], research on the actual mechanisms and the discourses through which right-wing populism undermines climate policy debates remain underexplored. 
Which elements of the right-wing populist approach to politics are particularly conflictive in their relationship to climate action? In what ways is right-wing populist rhetoric undermining climate policy in national political debates? To understand these issues, our paper explores the micro-scale of climate policy rhetoric of right-wing populists and their supporters. In order to do this, we analyse the discourse of Poland's Law and Justice (PiS) party. This is a particularly interesting case, as PiS has, since 2015, enjoyed full political power in the country, with a single-party majority in parliament and the support of the President Andrzej Duda. Importantly, PiS is a very clear example of RWP. Its ideology blends conservatism (e.g. a very strong emphasis on protecting 'traditional values' and families, close bonds with the Catholic Church), nationalism (exemplified by its historical policy and forging the myth of anti-communist nationalist guerrillas in the aftermath of World War II) and nativism (strong resistance to extra-European migration in the midst of the refugee crisis) [8]. Around these 'thick' ideologies, PiS constructs a clear 'thin centered' layer of populist ideas $[9,10]$, most importantly a very strong juxtaposition of the liberal 'elites' and the true Polish 'people' who are the 'Sovereign' in whose name PiS governs. Looking at PiS allows us to explore the specificity of the RWP outlook on climate policies.

We are interested in the political rhetoric on climate change and energy, particularly coal (Poland's major indigenous fossil fuel and source of emissions) that is disseminated through portals and websites related to right-wing weeklies. We focus on these because far right, nationalist, and fringe conservative media have a very close relationship with the PiS party. They were instrumental in its ascent to power in 2015, not only as sources of information alternative to the liberal mainstream, but also as hubs for a broader right-wing populist movement which became an additional driver of radicalization for the party, in a similar way as the Tea Party is for the US Republicans. Narratives spun by these outlets are also reproduced by supporters of the populist right on internet forums. Through this in depth reading, we distil several key lines or argument and narratives, which in our view exemplify the right-wing populist approach to climate policy globally.

Our analysis builds on the theoretical conceptualizations of right-wing populism and the characteristic elements of populist discourses, and applies these to the Polish case. We argue that while local references may be different in individual societies, RWP arguments and attitudes towards climate change and sustainable development policy are similar. We begin by constructing a theoretical framework, defining (right-wing) populism as a political phenomenon, the relationship of populist politicians and media (traditional and digital), and reviewing the literature on RWP and climate change. After discussing data gathering and 
laying out our method: combining the analysis of RWP discourse content, building on Laclau's discourse theoretical approach, with a classical rhetorical analysis of its form, we move to the analysis of the Polish case. We first provide some background on the Polish energy system's techno-economic context, and then discuss four features of the RWP discourse. These, we argue in the discussion and conclusion, can be universalized beyond the Polish experience, and in this we believe our paper contributes to the emerging research on populism and climate policy.

\section{Theoretical framework: right wing populism, media, and climate change}

\subsection{Defining right-wing populism}

The central point of populist movements is the opposition of people ('ordinary,' 'honest,' 'our' people) to the elites ('their,' 'corrupt,' 'spoiled'). Populism also suggests that politics should be an expression of the volonté générale (general will) of the people [10]. Even if populists form the power elite themselves, they are willing to speak out 'on behalf of the people' and threaten the 'elites' [11]. Populists define these 'spoiled elites' in a very broad sense - in economic ('business elites'), political ('political establishment') and cultural terms ('detached intellectuals, media, and scientific elites that promote political correctness'). The method of defining the elites depends on the 'thick' ideology around which populist discourse is cast, as well as strategic considerations.

Right-wing populists further strengthen their identity by defining the enemies of the state and/or the nation [12] (p. 64-65). This list may contain enemies who live in the state but are 'outside' the nation (e.g. immigrants) and also those who are inside the nation but succumb to 'external' influences and are 'against' the state. In addition to intellectuals and 'corrupt media,' this category of 'enemies' disloyal to their own country can be broadened, as we have seen in Waszczykowski's quip on cyclists and vegetarians. But RWP typically moves beyond populism-tout-court's emphasis on the People-Elite dichotomy, and contains two additional pillars: nativism (a particular exclusionary form of nationalism) and authoritarian attitude [12].

The language of nationalism typical of RWP groups may have different faces, but it is always a manifestation of a demand for cultural and national protectionism. Appealing to national interests - which are allegedly 'threatened'-is an easy means of political mobilisation of the populist right [13]. 
While right-wing populism and the radical (far) right and nationalist movements can share many features, and even an overlapping membership in organizations as well as parts of the constituency, in this article we focus primarily on RWP (for a discussion of Poland's far right and environmental discourses see [14]). The most important reason is that we want to explore the relationship between RWP rhetoric and political practice, and not merely look into far right political ideology. In the case of Poland, PiS is a right-wing populist force, which in the period analysed has also been the ruling party. While fringe right groups such as the National Radical Camp (Obóz Narodowo-Radykalny, ONR), the National Rebirth of Poland (Narodowe Odrodzenie Polski, NOP) and the All-Polish Youth are difficult to ignore, they occupy the margins of Polish politics, as PiS managed to take over much of their frames, rhetoric, as well as many politicians and voters [15] (p. 32). That said, the boundary between the PiS party and the typical extreme right is often fuzzy. There are many elements connecting these two environments (e.g. the cult of tradition and national identity, rejection of political correctness, anti-Communism) [16].

\subsection{Right-wing populists and climate change}

Why would right-wing populism be a threat to climate action? Lockwood provides two kinds of explanations: structuralist and ideological [7]. The former stress the vulnerability of those who have not benefited from the process of neoliberal transformation (and have been abandoned by the traditional left) to populist right-wing slogans. In this context, people from the lower classes, poorer earners and residents of neglected provinces are pointed out as potential proponents of nativist slogans and those that discourage action for clean energy or climate protection. The ideological approach, in turn, explains the climate scepticism of rightwing populists and their tendency to believe conspiracy theories, rejection of cosmopolitan responsibility for the whole world and reluctance to accept scientific universalism and new ideas. In our opinion, these two approaches do not have to be mutually exclusive; quite the contrary, they can complement one another. In this article, we focus on the ideological side of the populist right-wing narrative in Poland in relation to climate and energy policy.

Research conducted in Great Britain has confirmed that climate change scepticism correlates with conservative political views and traditional values [17]. An analysis of the relationship between political views and US climate change scepticism has brought similar results [18]. Surveys on large samples made it possible to show the scale of climate change scepticism and its correlation with different variables (e.g. knowledge and the level of 
information on climate change, as well as the level of civic activity and forms of political participation) [19].

Along with the offensive of right-wing populism in Europe, climate sceptic positions began to be articulated in RWP terms: the defence of national sovereignty, opposition to international elites and the maintaining economic and energy autarchy. As shown by studies on the attitude of the extreme right in the UK and Denmark to climate change, 'the primary concern of nationalists is therefore rarely the climate itself or changes to it, but new actors and conflicts which they see emerging in and through the climate debate, actors accused of using climate change as an excuse for attacking national sovereignty' [20] (p. 213). In this way, right-wing populists transfer the debate from the scientific level to the level of political and ideological conflict. The extreme right also shares many views with conservative climate change sceptics: 'criticism of mainstream scientists and the media as distorting climatechange communication; accusations against the mainstream as being alarmist and close to a religious cult; attacks against climate policies as being moneymaking scams; and the rejection of such policies as causing economic harm' [21] (p. 600). What distinguishes typical conservatives from the populist right in the aspect of climate is that the former express their arguments usually referring to cultural individualism [22], and the latter collectively defend the nation whose sovereignty is threatened by globalist climate policies [21].

Framed in nativist terms, RWP policy negates the need to handle environmental and energy issues at an international level [6], as this would involve the loss of sovereignty and subordination of national politics to international institutions that enforce and correct climate policy. Under the pretext of protecting the interests of the 'ordinary people,' right-wing populists try to ignore or diminish the importance of all international agreements aimed at protecting the environment and climate as allegedly threatening the domestic economy. Although climate scepticism may be a tool for lowering public support for a decarbonization and protecting the interests of traditional business elites (especially those related to the domestic industry) [23], it is usually associated with a more general cultural model dominated by distance to universal knowledge and scientific criticism. Also, the way in which the problem of climate change was described in some media, on which RWP political forces visibly played, was exposed to disinformation and drove a wedge between the international climate expert community and parts of the public [24]. In this sense, the general narrative of right-wing populists emphasising issues of national identity, national security, national sovereignty and scepticism towards universal knowledge can create a cultural atmosphere in 
which the issues of environmental protection and clean energy transition are marginalized [25].

\subsection{Populism and the media}

Our research builds on the assumption, that the 'public debate' can be accessed through the analysis of the media (traditional and 'social') and that it is not merely a reflection of conscious political strategies, but a discursive sphere which is constitutive for policy making. The deeper role of the media in democratic backsliding has until recently escaped the attention of most researchers. 'Whilst political studies traditionally tend to underplay the role of media in the advancement of illiberalism and media landscape is considered by political scientists merely as a contextual measure for the assessment of the scale of this phenomenon, questions can be asked about the scale and the depth of "new" political dynamics that illiberalism brings to media landscapes in the region' write Surowiec and Stetka in the introduction to a recent special issue considering the relationship of media and the populist wave in Central Europe. They even go as far as to suggest that the 'origins of illiberalism can be found in the origins of media systems in CEE, and in the ways the media landscape have developed' [26] (p. 4 and 5). The populist shift in the media is often identified with emphasis on the emotional sphere at the expense of reducing the importance of facts [27].

Populist ideological traits and characteristic narratives are distributed through various information channels, i.e. traditional media like newspapers and television, but increasingly the populist offensive takes place on the internet and on social media [28], where an individual recipient of messages is practically unable to verify facts in the flood of information. In this context, we can talk about web-populism [29]. Twitter activity helped Trump win the presidential election and the blog run by Bepe Grillo allowed him to launch the Five-Star Movement in Italy [11]. In Poland, some commentators attributed the victory of PiS' Andrzej Duda in the 2015 presidential election to a special internet campaign which was conducted using bots [30], and research has indeed shown the strategic deployment of fake bot accounts by PiS campaigners [31], while two 2019 scandals revealed 'bot farms' operating under governmental auspices. Because of the easy and cheap access to a broad audience, various right-wing populist movements are eager to reach for internet tools [32].

Although some claim that populism may be a strategy for uniting people for social change, they also admit that 'populism can refer to demagogy and propaganda, to manipulating the people in support of leaders and policies that are presented as if they are serving the interests of the many. Populism also creates unity by bringing people together 
against a common enemy' [33]. This is particularly easy when using social media [34]. In this sense, the distinguishing feature of right-wing populists is not only their ideology, but also their political style and mood. While a particularly emotional mood and focus on charismatic leaders are generally the features of all populisms [35], the style used by right-wing populists in campaigns often introduces 'a more negative, hardened tone to the debate' [36] and it is full of aggression and negative emotions [37].

It is worth remembering, however, that although the RWP uses social media, it does not give up traditional media. There is still interaction between old and new media, between information from the internet and traditional media [38]. Therefore, in order to analyse the form and content of the right-populist rhetoric on energy policy, coal use and climate change, it is worth analysing all possible communication channels-statements by politicians, opinions expressed in traditional media, as well as views and comments on the internet.

\section{$3 \quad$ Research design and methodology}

Is right-wing populism a threat to effective climate action? This is the general question, which motivates our research. Following the distinction proposed by Lockwood, we focus on ideological factors and formulate the specific research question of our study: what is the content of Polish right-wing populist discourse on climate and energy, and what rhetorical means are used to support RWP arguments? Our analysis and answer to the latter question contributes to answering the initial general question by pointing to both structures present in the Polish discourse and typical rhetorical and eristic tricks used, which we assume, can be attributed to RWP parties and movements elsewhere.

\subsection{Method}

We conduct an in-depth qualitative analysis of texts (media articles and online comments underneath them), which had two aims. Firstly following Ernesto Laclau [39,40], we treat populism as a discursive mode of political articulation. The tenet of this position, drawing on Laclau and Mouffe's Discourse Theory, is that language is performative and relational [41]. It is performative in the sense that it does not simply express or reflect but more profoundly constitutes social reality. Language is also relational in that meaning and social identities are constructed through contingent relations between terms (or signifiers). Actors produce, reproduce, and contest these relations through their discursive practices: they mobilize, weave together, and establish chains of connotations between pre-existing linguistic elements to 
construct arrangements of meaning, which is referred to as articulation [41] (p. 105). Populism is one such discourse. What makes a movement populist then is not its actual political or ideological contents, but the particular logic of articulation of that content [40] (p. 33). This logic is characterized by two processes: the construction of an equivalential chain between unsatisfied demands and the creation of an internal frontier dichotomizing the social. The former allows (particularly right-wing) populists to create logical links between different grievances, and bridging between legitimate and objective social injustices and griefs driven by prejudice or nativist ideology. The second feature, dichotomization of the social, leads to a Manichean distinction between positive and negative elements, which combined with populism's moral charge turn into 'good' and 'evil.' The populist discourse is constructed around a main nodal point - 'the People' or in case of nativist right-wing populists, often 'the Nation.' As emphasized by Laclau, 'there is no populism without discursive construction of an enemy' [40] (p. 39).

Drawing on Laclau's discursive approach, in the first step of our analysis we distil four key elements of the Polish right-wing populist discourse on climate and energy. Firstly, we identify a populist episteme, a broader logic that conditions meaning and allows to draw distinctions between things which are true and false. Further, we uncover the dichotomy between good and evil, showing which elements are associated with which morally charged pole. Finally, we identify the fourth element, indicating which actors are being cast in the role of enemies, especially internal, in the Polish case.

This allows us to structure the analysis of the content of right-wing populist discourse, and allows us to answer the first part of our question. What we also do is look at the form of RWP rhetoric, and we achieve this by applying concepts from classical rhetorical and eristic analysis to indicate which tools populists use to argue their case, e.g. Aristotle's and Schopenhauer's typologies of arguments [42,43]. Our objective is to indicate that while the discursive content may to a large extent be case-specific, some main themes, topoi, rhetorical strategies and eristic tricks used by RWP politicians and supporters might be generalizable, and rhetorical analysis opens the possibility for future comparative research. We share the opinion that 'although disinformation may share properties with information and misinformation (e.g., truth, accuracy, completeness, currency), disinformation is deliberately deceptive information' [48]. In the case of the information from the right-wing portals, we emphasise the importance of the intentions of their authors who wanted to undermine the arguments and attitudes raised by environmentalists. 


\subsection{Data gathering}

The analysis assumes links between the content of statements made by politicians, right-wing media and comments on the forums of right-wing portals. As Bennett and Kwiatkowski observe, there has been 'a diffusion of far-right discursive frames and strategies into mainstream Polish political discourse, when reacting to environmental issues,' and the rightwing media were pivotal in this process [14]. While the traditional media and their online versions remain in a feedback loop with the RWP politicians - either citing their statements, discussing them, conductive interviews, or commenting on the government's policies they provide RWP politicians with a sens of response their actions generate among most important referent groups and constituencies. Additionally, we include comments under the online articles, since this allows us to the micro-level of populist meaning making, and probe how supporters of PiS (and readers of the pro-governmental newspapers) react to the key ideological messages.

Studying right-wing media in Poland is particularly useful, due to their very close relationship with the PiS party and very broad readership. We study the web portals linked to Poland's major ultraconservative and right-wing populist weeklies: wPolityce.pl and Niezależna.pl. There are personal, ideological as well as financial links between these media and the PiS party and government. Since PiS took power, their publishers could count on large financial support from state-owned companies controlled by the government [44]. wPolityce.pl was created in 2010 and from the very beginning gathered journalists associated with the nationalist right. In June 2012, editors of the portal reported that there were 8.5 million page views monthly and 650,000 unique users [45]. Two years later, the number of users reached almost two million per month, and the number of monthly views exceeded 20 million. This allowed its creators to announce that they were the largest conservative, rightoriented portal in Poland [46]. According to Google Analytics, in May 2016, information from wPolityce.pl reached over four million users. The portal recorded a record-breaking result of 43.5 million page views, with nearly 13.5 million visits [47]. These data show that it is not a niche portal and it has a large impact on right-wing sympathisers in Poland. Its direct financial and personal connection with the weekly wSieci makes it one of the main media channels of the PiS party in Poland.

Journalists from the other portal, Niezalezina.pl, are associated with the weekly Gazeta Polska and daily Gazeta Polska Codziennie. Both of these printed newspapers present a hard right-wing nationalist orientation and provide the backing for the right wing of the populist PiS party. After 2007, when PiS lost power in snap elections, and particularly after the 2010 
plane crash near Smolensk where the PiS backed president Lech Kaczynski perishedcreating the basis for the party's new foundational myth-Gazeta Polska, forming regional and local Clubs, helped mobilize grassroots support for PiS and became the hub of right-wing civil society.

These right-wing weeklies, dubbing themselves the 'defiant media,' and pitching a populist narrative of representing the true voice of the Nation against cosmopolitan liberal urban elites and the mainstream media, were instrumental in PiS ascent to power in 2015. They were not only sources of information alternative to the liberal mainstream, but also hubs for a broader right-wing populist movement.

Our analysis covers articles and opinions that appeared on these portals primarily around the COP24 in Katowice, starting some weeks before and ending several weeks after. In the period between October 2018 and the end of February 2019, Niezależna.pl published 32 articles on topics such as coal, energy policy and climate change. In the same period, wPolityce.pl published 140 pieces on these topics. Among the analysed messages and texts, we have selected 42 that expressed the most frequently repeated arguments in defence of Polish coal and against climate change warnings. In our analysis, we have also used several articles from outside this period for illustrative purposes. To make it clear which material comes from the corpus of texts analysed and which is an illustrative addition from a different period, we italicize the quotes from our media sample.

\section{Poland's right-wing pro-governmental media and climate change arguments}

\subsection{Background:}

\subsubsection{The techno-economic context of Polish climate debates}

Poland's energy mix is dominated by indigenous coal, and since the country joined the European Union in 2004, it has been clear that it will do much to safeguard its domestic coal sector and resist pressures for ambitious harmonized decarbonisation efforts. After World War II, Poland underwent a massive electrification program based mainly on hard coal and later also lignite power plants. With over 213 Mio tones extracted in 1980, it was the biggest producer of coal in Europe except for the Soviet Union. To limit the dependency on coal already in the early 1970s the communist authorities began to explore the possibility of gaining nuclear energy capacity. However, in the aftermath of the Chernobyl catastrophe and 
due to sustained civil society pressures, project's abandonment and a moratorium on nuclear energy became one of the first decisions of the new democratic government in 1990 [49].

Shortly after the transition from state-socialist planned economy to capitalism in 1989, almost 99\% of power in Poland was generated in coal-fired power plants. Although by 2012 the share of power from renewable sources in the energy consumption increased to $9.6 \%$, over $55 \%$ of that energy came from biomass co-firing and a further $14 \%$ from large hydro power plants [50]. The power system is concentrated around large hard coal or lignite power plants, such as those in Bełchatów, Kozienice or Opole. 'Bełchatów,' located in central Poland is the largest lignite power plant in Europe and one of 25 largest power plants in the world, supplying some $20 \%$ of electricity to the national system. 'Kozienice' is the largest hard coal plant, alone providing $8 \%$ of electricity.

However, largely due to the high share of indigenous coal, Poland belongs to one of the least energy import dependent EU member states. In 2013 it imported 25.8\% of energy resources (EU average-53\%). Despite increasing coal imports from Russia, in 2013 coal exports to Germany allowed Poland to remain a net exporter.

\subsubsection{Poland's discourse on energy and climate}

The contemporary narrative about coal as a Polish national treasure is a continuation of rhetoric of the Communist period, where coal was called the foundation of the Polish economy and a national treasure. Coal was the basis of the country's electrification and the development of the chemical and metallurgical industries (coal converted into coke was needed for smelting steel from which tanks were produced for the Warsaw Pact armies). Coal would also be exchanged into foreign currencies in relations with Western countries [51]. From this perspective, Polish coal served not only energetic and economic, but also military and political functions [52]. Although its importance for the economy is smaller today, its political function remains important. This is clearly visible in media reports. In the article entitled 'Let us defend Polish coal: Many countries continue to invest in coal,' which appeared on the portal wPolityce.pl in October 2018, its author concludes: 'We can only hope that the government will stick to the line of Prime Minister Morawiecki, who made it clear a month ago: 'We want mines to remain our main element of energy sovereignty.' Poland has been waiting too long for this declaration' [53]. While the importance of military security was emphasised in the Communist period, 'energy sovereignty' is stressed today in the era of nationalist sentiments. In addition to 'sovereignty,' other words-spells in the language of the Polish right include 'nation,' 'homeland' and 'family.' Their 'magical' power is used to end 
any debate or criticism. In the right-wing dictionary, these words are to serve a sacred role, marginalize the opposition to their ideas and raise support for their political projects.

The underlying ideal of a complete energy autarchy, self-sufficiency in energy generation without the need to rely on any foreign partner, or at worst-diversification of supply - has informed Poland's energy policy at least since 2005, when the Law and Justice led coalition government took office, followed by the centre-right Civic Platform (Platforma Obywatelska-PO) and the agrarian Polish People's Party (Polskie Stronnictwo LudowePSL). Earlier research has shown that as far as climate policy is concerned, there was little or no variation among major Polish political parties [54]. The key premises of national energy policy have not changed, and the rhetoric involves constant juggling of only a handful important commonplaces: domestic coal, which was established already during the Communist era as a foundation of the economy and national pride [52]; the fear of Russia; a utopia of autarchy; and the resulting energy xenophobia that is the assumption that unless the Polish state exercises full control over entire energy systems and supply chains-from upstream to distribution - they are subject to foreign interference and thus vulnerable. ${ }^{1}$ All these commonplaces are fundamental for understanding the content of Polish right-wing populist climate policy discourse.

Poland's right-wing populist discourse, associated with the PiS party and after 2015 moving from fringe to mainstream, involves both economic and cultural arguments [55]. Populists oppose progressive socio-cultural transformation of the Polish society, seeing it as mimicry of the West or even a conspiracy undermining 'traditional values.' Instead, they propose the return to an idealised though un-specified past, which increases the importance of historical policy and the policy of 'national remembrance' [56].

For the purposes of this analysis, it should be noted that in its programme statement made before the 2015 elections, the PiS party called the incumbent liberal government's agreement to the EU 2030 Framework a 'terrible decision' brought on by political corruption and interference of other European nations into Poland's affairs, citing the 'risk of lowering GDP, increasing unemployment, and impeding energy production' [57,58]. As the populist right strengthened its position in Europe in the post-2015 period and the PiS party won an outright majority in Poland, the rhetoric of right-wing media became increasingly radical. Hence it is necessary to analyse media messages on climate change and energy policy of the PiS party. This makes it possible to understand the huge regress in environmental protection,

\footnotetext{
${ }^{1}$ Xenophobia here is used in the sense drawing on the original Greek 'fear of anything that is strange or foreign,' and not in its usual contemporary use as an element of or synonym for racism.
} 
which has been taking place in Poland after 2015 and constitutes a certain forecast of energy policy for the nearest future in the country ruled by an RWP majority.

The discussion on climate and energy, most importantly coal, is part of a wider rightwing populist discourse, the framework conditioning attitudes towards politically significant objects. It includes such elements as: the unwillingness to accept migrants under the pretext of protecting jobs [59]; promoting the traditional family model and dislike for LGBT communities; idealisation of the past and practising 'politics of remembrance' for the purposes of domestic and international policies; preferring the isolationist model of the economy emphasising the 'national colours' of capital ('Polish industry,' 'Polish banks,' 'Polish coal'); building an image of a regional superpower and a sense of national and economic sovereignty; promoting a centralised model of a strong state and the economy supervised by the 'state elites' at the expense of local initiatives and decentralised actions.

The analysis that organizes Poland's RWP discourse on climate change along the most important symbolic distinctions and dyadic oppositions. We begin by the description of the populist episteme, an anti-rationalist and anti-elitist logic of argumentation which emerges from the media analysis. We then look at those elements which are discussed with a visibly negative connotation - external forces and actors undermining 'sovereignty' of the nation. What follows is the depiction of what is to be safeguarded as positive-here right-wing populism's nativist core is exposed. Finally, we trace the search for enemies within the community, those who are 'inside the state' but allegedly 'outside the nation' - environmental activists.

\subsection{The populist episteme: Anti-elitism, irrationalism, and conspiracy theories}

\subsubsection{Rejection of rationality and a tendency for conspiratorial thinking}

An important element of the logic, which underlies much of climate sceptical communication in right-wing populist supportive media, is the selective use of verification and falsification, as short hands for the scientific method. Most importantly, this involves the use of stochastic and anecdotal evidence as alleged 'falsification' of theories based on timeseries data, such as the use of individual local weather events as 'falsifying' evidence for climate change. Ruth Wodak emphasises the aspect of the knowledge model in the discourse of right-wing populists and their support for 'common sense' at the expense of 'expert knowledge': 'all right-wing populist parties seem to endorse what can be recognised as the 
"arrogance of ignorance"; appeals to common-sense and anti-intellectualism mark a return to pre-modernist or pre-Enlightenment thinking' [62].

An example of this way of thinking may be sarcastic reports on the portal wPoltyce.pl on bitter frosts in the US in January 2019. However, this information was not presented in the context of climate change, but on the contrary, it undermined this change: 'In the US, the climate has warmed up so much that record frosts are coming' [60]. In turn, warnings from the COP 24 summit about the irreversible consequences of climate change were commented on the wPolityce.pl forum in the following way:

One eruption of a volcano such as Krakatau equals a couple of years of exhaust fumes from around the world. And these fools want to destroy car engines with their ecology! And, at the same time, they block cheap energy [61].

In a surprisingly 'poststructuralist' manner, the authors and readers of the right-wing media see all knowledge as political and a projection of power relations. Scientific and political opinions on climate change and the need for energy transformation, which are contrary to the dogmas of populists and opponents of clean energy, are discredited as 'naïve,' a manifestation of 'leftist propaganda', serving 'EU cliques' and 'foreign forces,' being a product of liberal media, 'ecologists' hysteria' and a part of 'political correctness.' We can see that behind every statement there is either a powerful ideology, or some hidden agency, which leads to the somewhat surprising conclusion that in the right-wing populist mind-set, there is no place for individual opinion, will or motivation (other than perhaps material, i.e. paid agents).

Undermining knowledge on the base of its politicization blends irrationality with a penchant for conspiracy theories. Articles and comments on right-wing portals often contain the so-called argumentum ad metum to strengthen their messages [64] (p. 164). It appeals directly to readers' emotions and is supposed to create a sense of fear in them. In the discussion about clean energy, the populist right shows these concepts as a way to take control of the economy, people and as an element of social engineering. This method of argumentation could be found on right-wing portals shortly after the COP 24 summit. On 17 December, an article entitled 'The COP 24 Climate Summit in Katowice is over, but the hysteria of climate defenders continues' was published on wPolityce.pl. In response to the environmentalists' claims, the author stated: 
Behind this alarmist tone, there is, of course, the left wing's passion for social engineering. As was the case with the popular warnings against overpopulation in the 1970s and 1980s, the conclusion is simple: you have to intervene to align the world with your ideological whims. And you can make money on it. Greenpeace and the rest live off this. The citizens pay the price [61].

This thesis received a massive response from right-wing commentators who made even more dramatic prophecies:

The leftist climate business based on lies, propaganda and willingness to eliminate cumbersome nations - depopulation is a real catastrophe [65].

There was already an ozone hole, acid rain, global cooling, etc. The cunning leftists will always find a reason to take money for nothing. Let's kick these dodgers to the trash [65].

In order to show the absurdities of environmental appeals and actions taken by the advocates of clean energy, the followers of the populist right use another eristic trick, i.e. argumentum ad consequentiam to emphasise the negative and dangerous consequences of succumbing to ecological politics:

It's about a new colonialism under the banners of leftist democracy and the fight for nature. There is no need to succumb to [them] because they will enslave us [66].

The whole swindle with the harmfulness of coal is aimed at a 'peaceful' takeover of Polish mines by obliging Germans [66].

Thus, the real danger is not an environmental catastrophe, but 'new colonialism' and the 'takeover of the Polish mining industry by the Germans.'

\subsubsection{A populist vision of 'nature': cognitive irrationalism and rejecting the Enlightenment legacy}

When environmentalists say 'let us protect the environment,' right-wing populists say 'let us protect sovereignty' and their nationalist supporters exclaim 'let us save and protect the nation' on internet forums. The narrative of the populist right in different contexts is more about the past than the future. Appealing to tradition often takes the form of argumentum ad traditionem - a way of arguing in which the sender of a message refers to solutions from the 
past to confirm their thesis and proves that something that worked in the past is right. According to all kinds of right-wing populists, rational and critical thinking is suspicious because it is associated with the Enlightenment, which is a symbolic beginning of moral decay. In Poland, where the Enlightenment was very weak or, as some say, did not occur at all, counter- Enlightenment dogmas are even more noticeable in public life [63].

Critical thinking involves a variety of views, which contradicts the simple, homogeneous and dogmatic positions of populist right-wing communities, for which the basic source of truth is the slogans expressed by 'leaders of the nation.' In practice, this leads to the censoring of thoughts and views that refute irrational myths, and also causes a tendency to favour national particularisms rather than universal and transnational knowledge.

Although the Polish far right also uses the term 'nature,' it has a completely different meaning than what mainstream, particularly scientific publications would see. The criterion for differentiating right-wing populists from the Greens is their attitude to the Enlightenment, science, and rational thinking. There has always been - and continues to be - a rejection by the populist right of 'Enlightenment universalism,' that is, 'a world view in which a system of places is a human, not a natural construction. In the nativist vision, "protection of nature" means, above all, the attachment of national groups to their "natural" places of origin' [68] (p. 237), their 'homelands.' Therefore, 'nature' has a cultural and ethnic character-for example, inhabiting a given area by people from a 'foreign' culture or tradition incompatible with 'nature' is against 'nature.' On the other hand, 'our domestic coal' is compatible with 'nature.' In this view, the word 'nature' becomes a synonym for the term 'tradition.'

\subsection{The Bad: European, international and foreign}

European Union (EU) institutions and political processes have a unique role to play in RWP rhetoric in Poland and beyond. Among the Polish populist right, 'Brussels' can be a placeholder for many negative phenomena, and to show a moral decay or a negative example, populist right-wing politicians in Poland and their supporters usually use examples from the EU. Argumentum ab exemplo is an eristic trick that involves using negative examples to illustrate the harmfulness of a given idea or policy. Populists treat the EU policy that calls for a low-carbon energy transition as not only a negative, but also an absurd activity. This type of comment can be found on the online forum of wPolityce.pl under the article describing the liberal opposition's demands for decarbonization and transition to renewable energy sources. These demands have been commented on as the idea of Brussels, and the EU itself is called 'euro-Commies' (Eurokomuna) ‘environmentalist euro-empire' and 'euro-brothel': 
I haven't heard so much nonsense for a long time. This is a simple way to deprive Poland of energy independence. The leftists and the liberals will do everything for Brussels, even if it was exceptional nonsense [69].

The annual coal production on the globe equals 7 billion tons $\left(7 \times 10^{9}\right)$, the annual coal production in the euro-commune is 50 million tons $\left(50 \times 10^{6}\right)$. The ratio of the two numbers, and thus the simply perceived impact of the 'eco-friendly euro-empire' on the situation is 0.0071!!! We are thus dealing with eco-terrorism, a new wave of the ideology of violence that will make it possible to smash our minds and impose inquisitional methods on those who try to be free [70].

It's not a 'comedy,' it's acting for foreign interests. We are to buy energy from the rulers of Europe [69].

Right-wing commentators use pathos to colour even the most aggressive comments on the forum. This is one of the hallmarks of the right-wing language. Pathos makes the statements more emotional, can help to build a community between the sender and the recipient and also helps to hide the deficiencies of the content. However, its most important function is to emphasise the importance of the topic. This is achieved by the use of powerful spell-words (e.g. 'energy independence'), exclamation marks and dramatic phrases ('It's not a comedy'). Speaking on behalf of the 'nation,' the populist right tends to emphasise the polarisation of political forces. On the one hand, there are those who admit that 'the nation has a right,' that all difficult issues must be 'handed over to the nation' and that 'decisions of the nation are irrefutable'; on the other hand, there are those who overlook 'our national interests' or 'serve foreign forces.' This eristic trick called argumentum ad populum [64] (p. 156) is also used in the debate on energy policy.

In addition to anti-EU accents, strong anti-German nationalism is a constant element of the populist narrative in Poland. This is often combined with anti-Russian attitudes, however, it has to be emphasized that Law and Justice, and even more the fringe nationalist groups to the right of PiS, are not exceptionally sceptical of Russia, by Polish standards. On the contrary, while in liberal circles a historically conditioned weariness of Russian influence meets a strong opposition to Vladimir Putin's authoritarian rule, the populist and nationalist right uses Russia as a commonplace in foreign policy imaginary, but on occasion can be heard praising some of Putin's policies or his general 'Realpolitik.' 
Statements on internet forums of the populist right contain a clear division into those who protect 'Polish energy independence', supporters of 'our coal' (the right, 'patriots,' 'real Poles') and 'them' who are 'plotting' (liberals, Germany, leftists, EU minions). 'They' seek to weaken 'our economy': 'Poland's energy and food independence, strong economy, efficient army and our own currency are the nightmare of Angela and Vladimir' [71].

It is worth noting that statements on the right-wing forums are a more radical version of the views and thoughts voiced by right-wing populist politicians. Under the article containing President Duda's statement: 'Do not worry, as long as I am the president of Poland, I will not allow anyone to murder Polish mining' [70], there are many comments reproducing this position, but in a radical version. In this way, hate speech against climate protection policy goes hand in hand with dislike for Germany and other countries:

Germans open new mines even at the cost of cutting down a hundred-year-old forest, and Polish mines are shut down and sold out [70].

Climate propaganda is one big financial scam. Germany will not allow Poland to develop at a rapid pace, so they will use climate change to block the development and thus increase energy prices to such an extent that Poland will be forced to buy energy from the Germans.

The problem is not our coal. We are poisoned by dust brought with the wind from Western Europe, from highly industrialised countries-Germany, the Netherlands, Belgium and France. It falls on us causing respiratory and cardiovascular diseases, etc.

These comments clearly show another feature of the right-wing discourse in Poland: a clear division into 'us' and 'them.' 'They' are Germans who block 'our development,' industrialised Western Europe which poisons 'us,' and all other countries that do business and 'criticise us.' Russians and Jews also appear as negative references. The linguistic image of the right-wing world in relation to climate change coincides with the other dimensions of collective life. On the one hand, there are 'them': foreigners, foreign powers, foreign interests and international conspiracies. On the other hand, there are 'patriots,' 'real Poles' and 'national interest.' This dichotomous vision based on nationalistic myths can apply in the same way to migration policy and international agreements for climate protection. 
Treating the problem of climate change and environmental protection as an obstacle to economic growth is a permanent element of the narrative of right-wing populists as well as market ultraconservatives [72]. In 2014, Australian prime minister Abbot, acting as host of a G20 summit, said that he did not wish the agenda to be 'cluttered' by subjects such as climate change 'that would take the focus from his top priority of economic growth' [73] (p. 72). Also Bolsonaro, the president of Brazil has complained that environmental policy is 'suffocating' the economy and promised to remove some protections for the Amazon rainforest, including by rolling back indigenous reserves, such as Raposa Serra do Sol-he has advocated for agriculture and mining exploration there [74].

The populist right in Poland has similar views: the economy and economic growth are to be more important than climate protection issues and clean energy. For this reason, the right-wing media and their experts warn against the effects of EU policy: 'EU regulatory changes put a lot of strain on coal-based electricity bills' [75]. On the portal wPolsce.pl, a right-wing expert threatened: 'The direction in which EU regulations are going will strongly affect the Polish economy and electricity bills in Poland' [75]. This style of argumentation is supposed to cause panic among the recipients of information. This is a typical example of argumentum ad metum, which refers to fear. This kind of arguments uses opponents' fears, phobias and obsessions for persuasion purposes. Appealing to anxiety is aimed at inducing rejection of views and solutions that may threaten us. Scaring the public with price increases, interference in national affairs and the loss of national and energy security is part of the 'culture of fear' [76], which is arguably deployed strategically by RWP forces to steer societal attitudes, or is part of a 'securitization' mechanism which allows the state to safeguard its powers in energy governance [77].

It turns out that the source of all evil is that 'coal is attacked in Poland,' whereas (as suggested in the statement, cunning and pragmatic) Germany say a lot about renewable energy and in practice - as the interviewee claims - they produce energy from coal. In the right-wing narrative, Germans play a symbolic role-they are a certain negative reference, as are the notions of 'communism,' 'liberalism' and 'Brussels.' These words are 'labels' that belong to certain categories of concepts which are supposed to obscure the vision of the social order that lies behind them. 


\subsection{The Good: native, rooted, and indigenous}

\subsubsection{Protection the national treasure: Coal, national security and sovereignty}

Populists' nativist orientation does not allow for a cosmopolitan outlook and responsibility for the challenges and problems of the modern world occurring at the supranational level. It is difficult to solve problems related to climate change without methodological cosmopolitism [79], which rejects the nation-centred outlook defining the framework of nationalist rightwing activities. According to right-wing populists, the political order is to be set according to the rules of a Westphalian nation-state system, and the policy pursued (including energy policy) is to be limited only to the territory of a particular state. Anything outside of it is claimed to be insignificant. What counts is only the interest of the nation state. This way of thinking is best illustrated by the following post on the wPolityce.pl forum:

We do not quite understand why Poland does not consume its brown coal deposits near the German border-Germans can mine coal on the other side of the Oder, and we can't do the same? Are we scared? Let's have the courage! [80]

The epistemological nationalism prominent among right-wing populists also stresses the rivalry between nation-states and supports national interests at the expense of a broader view of the problem. An example of this way of thinking is an interview with Professor Wojciech Nowak, director of the Centre of Energy at the Krakow's AGH University of Science and Technology entitled 'It is impossible to withdraw from coal overnight' on wPolityce.pl, who argued that 'coal is still in the game' [81].

The coal-based energy 'independence' or 'sovereignty' is the official aim and the position of the PiS government. Piotr Naimski, who has been the government plenipotentiary for strategic energy infrastructure since 2015, said in October 2018 that '[c]oal and supplying energy based on our own raw material, ensures long-term state security, for at least 30 years. ... It is a non-negotiable element of Poland's security in every dimension' [82]. President Duda expresses similar opinions about coal. On 4 December 2018, on the annual Miners' Day, he addressed a letter to them, stating that 'the mining industry and energy based on domestic mines are and, from a predictable perspective, will remain the foundation of Poland's raw material and energy security' [83].

The readers of portal Niezależna.pl support this position. One of them stated under the article describing President Duda's letter: 
Miners are power. Keep it up. Do not be fooled by smooth speech. Coal is our treasure. We can have cheap energy. Do not be bothered with the so-called ecological trend prohibiting mining and exploitation of coal. Let them say that to China or the US [83].

\subsubsection{Energy justice: national-yes, global-no}

Maintaining a national perspective rather than adopting a more cosmopolitan or 'planetary' outlook and accepting the responsibility global challenges is also associated with the preference for the often summoned but rarely defined 'national interest.' Sketching the framework of opposition between the left and the right, Norberto Bobbio argued that one of the main criteria differentiating these two political traditions is the attitude to equality [84]. However, the more important division line might be not equality in itself, but the 'reference object' of equality, justice and thus the addressee of policy [85]. Right-wing populists across Europe are eager to use the language of 'energy justice,' emphasize the energy poverty of marginalized groups, and accept these sector-specific grievances (e.g. the 'heat or eat' problem for low income households, new green taxes and levies, environmental policies targeting some consumer behaviours) under a common roof of elite exploitation of the people [86]. The same is true for Poland, where PiS has often opposed ambitious climate policy by referring to potential energy price hikes, and juxtaposed broader environmental concerns with regional development of impoverished localities [72]. However, energy justice in right-wing populist terms always has national or local referents. It is not global environmental justice, where the externalities of safeguarding the national constituency create injustice and harm others beyond border. When confronted with such claims on international for a, such as the UNFCCC or the European Union, PiS politicians emphasise the importance of 'national economic profit' and interests. An illustration of this position may be the opinion of Krzysztof Szczerski, former PiS deputy, currently the head of the office of PiS-backed president Andrzej Duda, on coal and the EU's Energy Union:

'Decarbonisation stands for the elimination of coal from European power generation Can it be called anything else than the death of Polish coal? This is the proposal of countries that do not have such a significant share of coal in the economy. And that means that Poland will have to eliminate this branch of the economy and replace coal mining with either external energy imports or renewable energy sources. So, we eliminate our own energy resource and become even more addicted to imports' [87]. 
The slogans of PiS politicians are clearly referred to on internet forums: 'The consent to the liquidation of mining and coal-based energy is nothing more than HIGH TREASON.' It is important to note that while the costs of energy for households - and so an argument referring to energy justice and the risk of increased energy poverty-is often called up as a justification for climate-sceptical policy moves at home and abroad, protecting coal has deeper roots and arguably realizes the interests of the energy sector incumbents more than any broader societal interest [52]. The political economic basis for this discursive gap is Poland's state-industrial energy complex, which creates a symbiotic relationship of state administration, the current political elite in power and the main players in the energy sector [88]. Poland has seen an unusually high number of persons passing through the metaphorical revolving door between the industry and the regulatory bodies which are meant to regulate it - there and back.

\subsection{Minorities, the aliens within: Leftist ecologists and Soros' minions}

According to the populist right in Poland, 'leftists' are all groups that reject the vision of the nationalist right: socialists, social democrats, anti-fascists, feminists, environmental activists and human rights defenders [16]. For the right-wing media and their readers, environmentalists are among the main elements of 'leftism,' which violates Polish tradition, threatens Polish interests and serves 'foreign forces.' As a commentator on the niezależna.pl forum states:

The so-called 'environmentalists' are a left-wing gang that was once supported by the KGB for years and is now sponsored by 'philanthropist' Soros! Look how they jumped away from Russia after Putin sent some commandos who took them off the occupied oil platform and put them in jail, where they spent about a year! Somehow, they are not going there again! And this is the way we should deal with this scum! They are completely unpunishable in Poland! [89]

The environmentalists' attitude is perceived on right-wing portals as a conscious manipulation to weaken the interests and significance of Poland:

Greenpeace openly acts against the interests of Poland using lies and manipulation concerning coal. It's time to throw the bastards out of Poland [90].

The so-called ecologists always forecast disaster just like Jehovah's Witnesses prophesise another end of the world. The comparison is not accidental because both of 
them don't know completely what they talk about. Ordinary fools or cynical thieves: it's worth repeating even more bullshit for big money [65].

The populist right in Central Europe (Poland, Hungary, Austria) have similar opponents who symbolise evil and threats to national interests: illegal migrants, Muslims and Islam, non-governmental organisations, the EU and the liberal media [91]. A special place in the populist and far right rhetoric is reserved for the Hungarian-American philanthropist of Jewish descent, George Soros. The populist right in Poland can thus combine ecologists' activism with Soros' activity and more or less overt anti-Semitic sentiments:

Greenpeace and WWF should be banned in Poland. And a whole bunch of 'nongovernmental' agents financed by Soros (or more precisely by his Rothschild employers). And no discussions about $\mathrm{CO}_{2}$ and coal. If they don't like it, they should just pay us [65].

On right-wing portals, environmentalists, also referred to as 'eco-terrorists,' are also accused of mere fraud and the desire to enrich themselves in campaigns to reduce $\mathrm{CO}_{2}$. Under the article that challenged and ridiculed the report entitled 'The Intergovernmental Panel on Climate Change (IPCC),' there were many comments pointing to the mercantile motivation of actions taken by environmental movements fighting against dangerous climate change:

The eco-terrorists have a paradise in Katowice, they can speak wisely and show off because UNFORTUNATELY they cannot be forbidden to say bullshit. And we only need to reduce $\mathrm{CO}_{2}$ at a cost of min. 100 billion dollars and we need to and we need to. How many activists will earn on this? [65]

These arguments appeal to the sympathisers of the populist right. Under the article entitled 'How to protect the climate and maintain economic development?' [78], which appeared in December 2018 on the occasion of the commencement of the COP 24 climate summit, the following statements prevailed:

The globalist-communist nits will put their hands deeper into our pockets pretending that they want to save the world.

Global WARMING, a new religion of the 21st century. A way to loot ordinary people. They ask us to pay for the air. 
It is the EU that imposes high so-called fees for $\mathrm{CO}_{2}$ emissions on Poland. It is the EU that strives to ensure that the Polish economy is not competitive. Who knows, maybe it will be a reason for a Polexit.

In the above-mentioned statements, proponents of clean energy appear to be the representatives of elites who, under the pretext of environmental protection, want to plunder 'ordinary people.' The EU is the main patron of these activities.

\section{Discussion: right-wing populist visions and their echo chamber in right-wing internet portals}

The analysis has shown the right-wing populist way of reasoning (section 4.2), and the core Manichean dichotomy between 'good' native and indigenous element supporting 'the nation' (4.3), and the 'evil' external forces that work towards it's deconstruction (4.4), often with the help of the 'Trojan horse' of elites and internal minorities (4.5). It also shows at least three levels of climate-related narratives used by the right in Poland: a) statements of politicians associated with the PiS party on energy policy; b) echoes of PiS politicians' statements subjected to argumentation and development in right-wing media; and c) comments reproduced, radicalised and commented on right-wing websites. All these communication channels are different manifestations of the same discourse. Though the scale of verbal aggression may differ and slightly different words are used, the same positions are expressed and similar arguments are used in relation to clean energy policy in the media, statements of right-wing politicians and on internet forums commenting on these statements (Table 1).

The language of right-wing populist climate change sceptics in Poland generally has the features of arguments expressed by the far right rather than by typical conservatives from the US or Western Europe. This is evidenced by the fact that it does not refer to arguments oriented on cultural individualism, but appeals to the nation, 'national sovereignty' and the defence of 'Polish coal' treated as a national symbol. Just like the far right in Western Europe, PiS' narrative about climate change and energy has been shifted from the scientific-rational area to the sphere of ideology and unverifiable myths. This narrative also contains nativist accents, anti-German attitudes and its more radical internet version includes anti-Semitic threads.

It is difficult to find any support for decarbonisation in the materials posted on rightwing websites related to the PiS party. The topic of coal defence is rather part of a larger 
campaign directed against EU policy. In this approach, the discourse on energy policy can be treated as yet another dimension of the cultural and ideological opposition of the Eastern European periphery countries against the EU core countries [92]. In the case of Poland and the right-wing narrative, this would mean that the poorer and perhaps technologically less developed areas of Eastern Europe defend their political independence and cultural identity. In the right-wing narrative, the economic and technological deficit is compensated for with a sense of moral superiority and ideological-cultural story about the defence of national sovereignty.

\section{Conclusion}

The analysis of the arguments raised in Poland's right-wing populist-linked media concerning climate change and clean energy shows that the development of renewable energy and the abandonment of coal in the energy industry are not only technological and financial issues. These are primarily cultural, ideological and political problems. If energy policy is approached from the perspective of a political game for more general issues, such as defence or undermining the principles of liberal democracy, the conflict over coal and climate scepticism may be another area of social tensions, polarisation of society and undermining the principles of liberal democracy. The same happened with the artificially created hysteria around the issue of refugees in 2015, as well as in some countries (Poland, Italy) around the social attitude towards vaccines $[93,94]$. These topics also activated right-wing populists and undermined the consensus of liberal democracies around these issues.

If we admit that the populist right-wing ideology concerning the issue of climate change is not only an expression of prejudices and phobias against the 'corrupt West,' science and leftist ecologists, but it is also 'an ideological veil' used to defend real political interests, e.g. interests of mining unions which have close links to PiS. These incumbent interests and calculations of the ruling populists, however, affect the situation on the supranational level. The example is the EU summit in June 2019, at which the prime minister of the PiS government blocked (with the support of Viktor Orbán, the prime minister of the Hungarian populist government) the EU moves towards the 2050 zero carbon goal [95].

Although the phenomenon of right-wing populism in the context of energy exists in core [96], periphery [97] and semi-periphery countries, this phenomenon must be constantly analysed in every part of the world. This is important in core countries because of their political and model-forming functions - they determine technological, cultural and energy 
models for the rest of the world. Periphery countries are important due to the scale of the area they occupy and their enormous demographic dynamics. In turn, developments in semiperiphery countries (such as Poland and other Eastern European countries) will strongly affect sustainable development throughout the European continent and determine the potential of the mining industry in Russia - the sooner Eastern European countries enter the path of clean energy development, the faster they will integrate with the energy system of Western European countries. In this sense, they will be less dependent on Russian coal and oil. On the other hand, dependence on traditional energy sources will make these economies less competitive in the long run-even the cheap Eastern European workforce will not offset the costs of more expensive traditional energy. Sustaining the traditional energy model (advocated by the populist right) means that the semi-periphery character of this region will only be perpetuated. From this perspective, the conservative dogmas on coal and the energy discourse of the populist right should be treated not only as a form of ideology but also as a practical and useful tool for shaping the framework of the economic and political order. Under Eastern European conditions, the dominance of the populist right in the political sphere would deepen the distance to the EU core countries. In the energy dimension, this would involve being at the mercy of supplies of raw materials from Russia. It means that the debate about the existing energy model is not politically neutral - the weaker the left in Eastern Europe [98] and the more fragmented the ecological movement [99], the greater the threat is that the populist right-wing dogmas and disinformation about clean energy will dominate in the public sphere. Naturally, a completely different topic to consider is what attitude leftist populists have towards energy policy. Under the present conditions, however, this is a more theoretical issue than the very actual challenges posed by the populist right.

\section{References}

[1] D. Wantuch, Skandal na szczycie klimatycznym w Katowicach. Niewiarygodne słowa prezydenta Dudy. http://wyborcza.pl/7,155287,24238144,skandal-na-szczycieklimatycznym-w-katowicach-niewiarygodne.html, 3 December 2018 (accessed 25 March 2019).

[2] BBC News, Trump on climate change report: 'I don't believe it.' https://www.bbc.com/news/world-us-canada-46351940, 26 November 2018 (accessed 25 March 2019). 
[3] A. Forrest, Trump confuses weather with climate change again: 'Wouldn't be bad to have a little good old fashioned Global Warming right now!'

https://www.independent.co.uk/news/world/americas/us-politics/donald-trump-twitterclimate-change-weather-global-warming-latest-a8737326.html, 20 January 2019 (accessed 25 March 2019).

[4] J. Watts, Brazil's new foreign minister believes climate change is a Marxist plot. https://www.theguardian.com/world/2018/nov/15/brazil-foreign-minister-ernesto-araujoclimate-change-marxist-plot, 15 November 2018 (accessed 25 March 2019).

[5] XXX, Environmental awareness and higher education: Differences in knowledge and the approach to ecology between students of technical sciences and the humanities in Poland, Appl. Environ. Educ. Comm. 17(2) (2018) 150-160.

https://doi.org/10.1080/1533015X.2017.1388196.

[6] C. Fraune, M. Knodt, Sustainable energy transformations in an age of populism, post-truth politics, and local resistance, Energy Res. Soc. Sci. 43 (2018) 1-7.

https://doi.org/10.1016/j.erss.2018.05.029.

[7] M. Lockwood, Right-wing populism and the climate change agenda: Exploring the linkages, Environ. Politics 27(4) (2018) 712-732. https://doi.org/10.1080/09644016.2018.1458411.

[8] B. Stanley, A new populist divide? Correspondences of supply and demand in the 2015 Polish parliamentary elections, East Eur. Politics Soc. 33(1) (2019) 17-43. https://doi.org/10.1177/0888325418783056.

[9] B. Stanley, The thin ideology of populism, J. Political Ideol. 13(1) (2008) 95-110. https://doi.org/10.1080/13569310701822289.

[10] C. Mudde, C. Rovira Kaltwasser, Populism: A Very Short Introduction, Oxford University Press, New York, 2017.

[11] J.-W. Müller, What Is Populism?, University of Pennsylvania Press, Philadelphia, PA, 2016.

[12] C. Mudde, Populist radical right parties in Europe, Cambridge University Press, Cambridge, UK, 2007.

[13] A.A. Ellinas, The Media and the Far Right in Western Europe. Playing the Nationalist Card, Cambridge University Press, Cambridge, UK, 2010.

[14] S. Bennett, C. Kwiatkowski, The environment as an emerging discourse in Polish farright politics, in: B. Forchtner (Ed.), The Far Right and the Environment: Politics, Discourse and Communication, Routledge, London, 2019, pp. 237-254. 
[15] B. Pytlas, Radical right parties in Central and Eastern Europe: Mainstream party competition and electoral fortune, Routledge, London, 2015.

[16] XXX, 'The national music scene': the analysis of the Nazi rock discourse and its relationship with the upsurge of nationalism in Poland, Ethn. Racial Stud. 2018. https://doi.org/10.1080/01419870.2018.1554224.

[17] W. Poortinga, A. Spence, L. Whitmarsh, S. Capstick, N.F. Pidgeon, Uncertain climate: An investigation into public scepticism about anthropogenic climate change, Global Environ. Chang. 21(3) (2011) 1015-1024. https://doi.org/10.1016/j.gloenvcha.2011.03.001.

[18] R.E. Dunlap, A.M. McCright, A widening gap: Republican and democratic views on climate change, Environment 50(5) (2008) 26-35. https://doi.org/10.3200/ENVT.50.5.2635.

[19] A. Engels, O. Hüther, M. Schäfer, H. Held, Public climate-change skepticism, energy preferences and political participation, Global Environ. Chang. 23(5) (2013) 1018-1027. https://doi.org/10.1016/j.gloenvcha.2013.05.008.

[20] B. Forchtner, C. Kølvraa, The nature of nationalism: Populist radical right parties on countryside and climate, Nat. Cult. 10(2) (2015) 199-224. https://doi.org/10.3167/nc.2015.100204.

[21] B. Forchtner, A. Kroneder, D. Wetzel, Being skeptical? Exploring far-right climatechange communication in Germany, Environ. Commun. (12)5 (2018) 589-604. https://doi.org/10.1080/17524032.2018.1470546.

[22] S.B. Capstick, N.F. Pidgeon, What is climate change scepticism? Examination of the concept using a mixed methods study of the UK public, Glob. Environ. Change 24 (2014) 389-401. https://doi.org/10.1016/j.gloenvcha.2013.08.012.

[23] L. Kammermann, C. Dermont, How beliefs of the political elite and citizens on climate change influence support for Swiss energy transition policy, Energy Res. Soc. Sci. 43 (2018) 48-60. https://doi.org/10.1016/j.erss.2018.05.010.

[24] R.E. Dunlap, Climate change skepticism and denial: An introduction, Am. Behav. Sci. 57(6) (2013) 691-698. https://doi.org/10.1177/0002764213477097.

[25] S. Batel, P. Devine-Wright, Populism, identities and responses to energy infrastructures at different scales in the United Kingdom: A post-Brexit reflection, Energy Res. Soc. Sci. 43 (2018) 41-47. https://doi.org/10.1016/j.erss.2018.05.011.

[26] P. Surowiec, V. Štětka, Introduction: media and illiberal democracy in Central and Eastern Europe, East Eur. Politics 2019. https://doi.org/10.1080/21599165.2019.1692822. 
[27] M. Higgins, Mediated populism, culture and media form, Palgrave Communications 3 (2017). https://doi.org/10.1057/s41599-017-0005-4.

[28] P. Gerbaudo, Social media and populism: an elective affinity?, Media Cult. Soc. 40(5) (2018) 745-753. https://doi.org/10.1177/0163443718772192.

[29] M. Anselmi, Populism: An Introduction, Routledge, London and New York, 2018, ch. 15, 'Media populism.'

[30] W. Czuchnowski, Boty w służbie Dudy. Jak manipulowano internetem w kampanii 2015

r. [Bots in the service of Duda: How the internet was manipulated in the 2015 campaign]. http://wyborcza.pl/7,75398,23917763, boty-w-sluzbie-dudy-jak-manipulowano-internetemw-kampanii.html, 14 September 2018 (accessed 26 March 2019).

[31] R. Gorwa, Computational propaganda in Poland: False amplifiers and the digital public sphere, University of Oxford, Oxford, UK, Working Paper No.2017.4.

https://blogs.oii.ox.ac.uk/politicalbots/wp-content/uploads/sites/89/2017/06/CompropPoland.pdf (accessed 25 November 2019).

[32] M. Caiani, L. Parenti, The Italian extreme right and its use of the Internet: a 'bi-front' actor?, in: A. Mammone, E. Godin, B. Jenkins (Eds.), Varieties of Rightwing Extremism in Europe, Routledge, Abingdon, UK, 2013, pp. 217-232.

[33] A. Kavada, Editorial: media and the 'populist moment,' Media Cult. Soc. 40(5) (2018)

742-744. https://doi.org/10.1177/0163443718772144.

[34] G. Mazzoleni, R. Bracciale, Socially mediated populism: the communicative strategies of political leaders on Facebook, Palgrave Communications 4, 50 (2018).

https://www.nature.com/articles/s41599-018-0104-X.

[35] M. Canovan, Trust the People! Populism and the Two Faces of Democracy. Political Stud. 47(1) (1999) 2-16. https://doi.org/10.1111/1467-9248.00184.

[36] T. Immerzeel, M. Pickup, Populist radical right parties mobilizing 'the people'? The role of populist radical right success in voter turnout, Elect. Stud. 40 (2015) 347-360. https://doi.org/10.1016/j.electstud.2015.10.007.

[37] J.E. Oliver, W.M. Rahn, Rise of the Trumpenvolk: Populism in the 2016 Election, Ann. Am. Acad. Pol. \& Soc. Sci. 667(1) (2016) 189-206. https://doi.org/10.1177/0002716216662639.

[38] J. Postill, Populism and social media: a global perspective, Media Cult. Soc. 40(5) (2018) 754-765. https://doi.org/10.1177/0163443718772186.

[39] E. Laclau, On Populist Reason. Reprint edition, Verso, London and New York, 2005. 
[40] E. Laclau, Populism: What's in a Name?, in: F. Panizza (Ed.), Populism and the Mirror of Democracy, Verso, London, 2005, pp. 32-49.

[41] E. Laclau, C. Mouffe, Hegemony and Socialist Strategy: Towards a Radical Democratic Politics. 2nd edition, Verso, London and New York, 2001.

[42] Aristotle, Rhetoric. http://classics.mit.edu/Aristotle/rhetoric.html (accessed 25 November 2019).

[43] A. Schopenhauer, The Art Of Controversy. http://coolhaus.de/art-of-controversy/ (accessed 25 November 2019).

[44] G. Rzeczkowski, Jak rząd kupuje propagandę. Szmalu nie żal, Polityka, 24 April 2018. https://www.polityka.pl/tygodnikpolityka/kraj/1746368,1,jak-rzad-kupuje-propagande.read (accessed 26 March 2019).

[45] wPolityce.pl, Dziękujęmy naszym Czytelnikom! I teraz dajemy jeszcze więcej informacji i publicystyki. Cztery dobre wiadomości. https://wpolityce.pl/polityka/134463-

dziekujemy-naszym-czytelnikom-i-teraz-dajemy-jeszcze-wiecej-informacji-i-publicystykicztery-dobre-wiadomosci, 16 June 2012 (accessed 26 march 2019).

[46] M. Karnowski, Portal wPolityce.pl ma już cztery lata. Dziękujemy za Państwa wsparcie! 'Presja ma sens!' i 'Pilnuj Polski!' — to przecież nasze wspólne hasła. https://wpolityce.pl/media/203243-portal-wpolitycepl-ma-juz-cztery-lata-dziekujemy-zapanstwa-wsparcie-presja-ma-sens-i-pilnuj-polski-to-przeciez-nasze-wspolne-hasla, 2 July 2014 (accessed 26 March 2019).

[47] wPolityce.pl, Portal wPolityce.pl ma już ponad 4 miliony użytkowników. W planach więcej kultury i codzienne wideokomentarze. https://wpolityce.pl/media/254169-portalwpolitycepl-ma-juz-ponad-4-miliony-uzytkownikow-w-planach-wiecej-kultury-icodzienne-wideokomentarze, 28 May 2015 (accessed 26 March 2019).

[48] N.A. Karlova, K.E. Fisher, A social diffusion model of misinformation and disinformation for understanding human information behavior, Inf. Res. 18(1) (2013), paper 573. http://InformationR.net/ir/18-1/paper573.html (accessed 25 November 2019).

[49] K. Szulecki, T. Borewicz, J. Waluszko, A Brief Green Moment: The emergence and decline of Polish anti-nuclear and environmental movement, Interface 7(2) (2015) 27-48.

[50] K. Szulecki, Poland's renewable energy policy mix: European influence and domestic soap opera, CICERO Working Paper 1 (April 2017). doi: 10.13140/RG.2.2.13403.57120.

[51] E. Bendyk, U. Papajak, M. Popkiewicz, M. Sutowski, Polski węgiel, Wydawnictwo Krytyki Politycznej, Warszawa, 2015. 
[52] M. Kuchler, G. Bridge, Down the black hole: Sustaining national socio-technical imaginaries of coal in Poland, Energy Res. Soc. Sci. 41 (2018) 136-147. https://doi.org/10.1016/j.erss.2018.04.014.

[53] M. Szołucha, Brońmy polskiego węgla. Wiele krajów ciągle w węgiel inwestuje. https://wpolityce.pl/gospodarka/417581-bronmy-polskiego-wegla, 21 October 2018 (accessed 26 March 2019).

[54] K. Marcinkiewicz, J. Tosun, Contesting climate change: Mapping the political debate in Poland, East Eur. Politics 31(2) (2015) 187-207.

https://doi.org/10.1080/21599165.2015.1022648.

[55] XXX, Multimodal analysis of the nationalist discourse and historical inspirations of the spectacle of the populist right in Poland between 2015 and 2017, Discourse, Context \& Media 26 (2018) 135- 143. https://doi.org/10.1016/j.dcm.2018.07.005.

[56] XXX, Nation, national remembrance, and education-Polish schools as factories of nationalism and prejudice, Natl. Pap. 46(6) (2018) 1046-1062. https://doi.org/10.1080/00905992.2017.1381079.

[57] Program Prawa I Sprawiedliwości 2014. http://www.pisblonie.pl/image/files/program_pis_2014.pdf (accessed 27 June 2019).

[58] K. Szulecki, A. Ancygier, The new Polish government's energy policy: expect more State, less market. https://energypost.eu/new-polish-governments-energy-policy-expectstate-less-market/, 30 October 2015 (accessed 30 September 2019).

[59] XXX, Offshoring, labour migration and neoliberalisation: nationalist responses and alternatives in Eastern Europe, Econ. Labour Relat. Rev. 29(1) (2018) 97-117. https://doi.org/10.1177/1035304617739759.

[60] wGospodarce.pl, W USA klimat tak się ocieplił, że idą rekordowe mrozy. http://wgospodarce.pl/informacje/59423-w-usa-klimat-tak-sie-ocieplil-ze-ida-rekordowemrozy, 29 January 2019 (accessed 26 March 2019).

[61] A. Rybińska, '12 lat do katastrofy.' Szczyt klimatyczny COP24 w Katowicach się skończył, ale histeria obrońców klimatu trwa. https://wpolityce.pl/polityka/426043-cop24sie-skonczyl-histeria-obroncow-klimatu-trwa, 17 December 2018 (accessed 26 March 2019).

[62] R. Wodak, The Politics of Fear. What Right-Wing Populist Discourses Mean, Sage, London, 2015, chapter 1: 'Populism and Politics: Transgressing Norms and Taboos.' 
[63] XXX, Kontrreformacja, nihilizm czy Oświecenie? [Counter-reformation, nihilism or the Enlightenment?], in: XXX (Ed.), Dogmatyzm, rozum, emancypacja. Tradycje Oświecenia we współczesnym społeczeństwie polskim, Scholar, Warszawa, 2005.

[64] L. Polkowska, Język prawicy, Wydawnictwo UKSW, Warszawa, 2015.

[65] niezalezna.pl, COP24: ekolodzy wieszczą 'katastrofę.' https://niezalezna.pl/forum/248511-cop24-ekolodzy-wieszcza-katastrofe, 3 December 2018 (accessed 26 March 2019).

[66] wPolityce.pl, Grzegorz Długi (Kukiz'15): Przerażające są te ciągłe ataki na węgiel, który ma być jedynym powodem smogu. https://wpolityce.pl/polityka/426879-wywiad-dlugismog-nie-wegiel-jest-winny-tylko-czlowiek, 23 December 2018 (accessed 26 March 2019).

[67] U. Eco, Five Moral Pieces, transl. by Alastair McEwen, Harcourt, New York, 2002.

[68] E. Turner-Graham, 'An intact environment is our foundation of life': the Junge Nationaldemokraten, the Ring Freiheitlicher Jugend and the cyberconstruction of nationalist landscapes, in: A. Mammone, E. Godin, B. Jenkins (Eds.), Varieties of Rightwing Extremism In Europe, Routledge, Abingdon, UK, 2013, pp. 233-248.

[69] wPolityce.pl, Komedia! Nowoczesna postuluje całkowite odejście od węgla, a jednocześnie jest przeciwko budowie elektrowni atomowej. Liczy na OZE. https://wpolityce.pl/polityka/428866-nowoczesna-postuluje-calkowite-odejscie-od-wegla, 9 January 2019 (accessed 26 March 2019).

[70] niezalezna.pl, Prezydent stawia sprawę jasno. Andrzej Duda: nie pozwolę, by zamordowano polskie górnictwo. https://niezalezna.pl/forum/248653-prezydent-stawiasprawe-jasno-andrzej-duda-nie-pozwole-by-zamordowano-polskie-gornictwo, 4 December 2018 (accessed 26 March 2019).

[71] P. Nisztor, Węgiel — polskie dobro narodowe. https://niezalezna.pl/forum/242517wegiel-polskie-dobro-narodowe, 25 October 2018 (accessed 26 March 2019).

[72] J. Szulecka, K. Szulecki, Analysing the Rospuda river controversy in Poland: Rhetoric, environmental activism, and the influence of the European Union, East Eur. Politics 29(4) (2013) 397-419. https://doi.org/10.1080/21599165.2013.836701.

[73] J. Vogler, Climate Change in World Politics, Palgrave Macmillan, Basingstoke 2016.

[74] L. Viscidi, N. Graham, Brazil Was a Global Leader on Climate Change. Now It's a Threat. https://foreignpolicy.com/2019/01/04/brazil-was-a-global-leader-on-climatechange-now-its-a-threat/, 4 January 2019 (accessed 26 March 2019). 
[75] wPolsce.pl, Marcin Roszkowski: Zmiany regulacyjne UE bardzo obciążają rachunek za prąd robiony z węgla. http://wpolsce.pl/magazyn/6127-marcin-roszkowski-zmianyregulacyjne-ue-bardzo-obciazaja-rachunek-za-prad-robiony-z-wegla, 5 December 2018 (accessed 26 March 2019).

[76] XXX(Eds.), O kulturze strachu i przemyśle bezpieczeństwa [On the Culture of Fear and Security Industry], Oficyna Naukowa, Warszawa, 2015.

[77] K. Szulecki, Securitization and state encroachment on the energy sector: Politics of exception in Poland's energy governance, Energy Policy 136 (2020). https://doi.org/10.1016/j.enpol.2019.111066.

[78] wPolityce.pl, Jak ochronić klimat i utrzymać rozwój gospodarczy? Prezydent przedstawia tezy Deklaracji Śląskiej: 'Polacy zrobili wiele na rzecz środowiska.' https://wpolityce.pl/polityka/423875-prezydent-przedstawia-tezy-deklaracji-slaskiejszczegoly, 3 December 2018 (accessed 26 March 2019).

[79] U. Beck, E. Grande, Cosmopolitan Europe, Polity Press, Cambridge, 2007.

[80] wPolityce.pl, Tak potrafią tylko oni! 'GW' próbowała udowodnić, że nie potrzebujemy węgla. Z jej tekstu wynika jednak co innego. https://wpolityce.pl/polityka/424232-takpotrafia-tylko-oni-gw-sama-sobie-zaprzeczyla, 5 December 2018 (accessed 26 March 2019).

[81] wGospodarce.pl, Odejść od węgla nie da się z dnia na dzień. Róbmy to stopniowo. http://wgospodarce.pl/informacje/56983-odejsc-od-wegla-nie-da-sie-z-dnia-na-dzienrobmy-to-stopniowo, 28 November 2018 (accessed 26 March 2019).

[82] wPolityce.pl, Wreszcie ktoś powiedział to głośno! Naimski: Węgiel to bezpieczeństwo energetyczne Polski na długie lata. https://wpolityce.pl/gospodarka/417204-naimskiwegiel-to-bezpieczenstwo-energetyczne-polski, 18 October 2018 (accessed 26 March 2019).

[83] niezalezna.pl, Prezydent i premier o polskim górnictwie. https://niezalezna.pl/248717prezydent-i-premier-o-polskim-gornictwie, 4 December 2018 (accessed 26 March 2019).

[84] N. Bobbio, Left and Right: The Significance of a Political Distinction, University of Chicago Press, Chicago, 1996.

[85] A. Derks, Populism and the ambivalence of egalitarianism. How do the underprivileged reconcile a right wing party preference with their socio-economic attitudes? World Polit. Sci. 2(3) (2006). https://doi.org/10.2202/1935-6226.1012 (accessed 30 September 2019). 
[86] M. Bierbach, Climate protection: Where do the EU's right-wing populists stand?, Deutsche Welle. https://p.dw.com/p/3E8s3, 26 February 2019 (accessed 25 November 2019).

[87] wPolityce.pl, Szczerski: Dekarbonizacja oznacza eliminację węgla z energetyki europejskiej. Jak to nazwać inaczej niż śmiercią polskiego górnictwa? https://wpolityce.pl/gospodarka/237984-szczerski-dekarbonizacja-oznacza-eliminacje$\underline{\text { wegla-z-energetyki-europejskiej-jak-to-nazwac-inaczej-niz-smiercia-polskiego-gornictwa- }}$ nasz-wywiad, 20 March 2015 (accessed 26 March 2019).

[88] K. Szulecki, The revolving door between politics and dirty energy in Poland: A governmental-industrial complex, in: P. Bartlett Quintanilla, Pamela, P. Cummins-Tripodi (Eds.), Revolving doors and the fossil fuel industry: Time to tackle conflicts of interest in climate policy-making, Greens/EFA Group in the European Parliament, Brussels, 2018, pp. 98-107.

[89] niezalezna.pl, Andrzej Duda podpadnie ‘ekologom.' https://niezalezna.pl/251193andrzej-duda-podpadnie-ekologom, 20 December 2018 (accessed 26 March 2019).

[90] wPolityce.pl, Minister Kowalczyk: Mówienie tylko o węglu jako przyczynie emisji dwutlenku węgla, to zakłamywanie obrazu. https://wpolityce.pl/gospodarka/424440-naszwywiad-kowalczyk-emisja-bierze-sie-nie-tylko-z-wegla, 6 December 2018 (accessed 26 March 2019).

[91] R. Wodak, Entering the 'post-shame era': the rise of illiberal democracy, populism and neo-authoritarianism in EUrope, Global Discourse 9(1) (2019) 195-213. https://doi.org/10.1332/204378919X15470487645420.

[92] T. Zarycki, Peryferie. Nowe ujęcie zależności centro-peryferyjnych, Scholar, Warszawa, 2009.

[93] D.A. Broniatowski, A.M. Jamison, S. Qi, L. AlKulaib, T. Chen, A. Benton, S.C. Quinn, M. Dredzeet, Weaponized Health Communication: Twitter Bots and Russian Trolls Amplify the Vaccine Debate, Am. J. Public Health 108(10) (2018) 1378-1384. https://doi.org/10.2105/AJPH.2018.304567.

[94] XXX, J. Lisiewicz-Jakubaszko, The anti-vaccine movement in Poland: The sociocultural conditions of the opposition to vaccination and threats to public health, Vaccine 37(11) (2019) 1491-1494. https://doi.org/10.1016/j.vaccine.2019.01.073.

[95] T. Bielecki, Polska jako klimatyczny hamulcowy to nie jest zaskoczenie. Co wydarzyło się na szczycie w Brukseli? http://wyborcza.pl/7,75399,24921699,polska-jako- 
klimatyczny-hamulcowy-to-nie-jest-zaskoczenie-co.html, 21 June 2019 (accessed 27 June 2019).

[96] I. Wallerstein, World-systems Analysis: An Introduction, Duke University Press, Durham, NC, 2004.

[97] P.A. Trotter, R. Maconachie, Populism, post-truth politics and the failure to deceive the public in Uganda's energy debate, Energy Res. Soc. Sci. 43 (2018) 61-76. https://doi.org/10.1016/j.erss.2018.05.020.

[98] XXX, Non-alternative reality? On the misery of the Left in Eastern Europe: the case of Poland, Journal of Contemporary Central and Eastern Europe 25(1) (2017) 63-84. https://doi.org/10.1080/0965156X.2017.1339976.

[99] J. Szulecka, K. Szulecki, Between domestic politics and ecological crises: (De) legitimization of polish environmentalism, Environ. Politics 2019. https://doi.org/10.1080/09644016.2019.1674541. 